\title{
Nutrient Accumulation and
}

\section{Availability in Compost-amended Turfgrass Soil}

\author{
Alan L. Wright ${ }^{1}$ \\ Everglades Research \& Education Center, University of Florida, 3200 \\ E. Palm Beach Road, Belle Glade, FL 33430-4702
}

Tony L. Provin, Frank M. Hons, David A. Zuberer, and

Richard H. White

Soil and Crop Sciences Department, Texas A\&M University, 2474 TAMU, College Station, TX 77843-2474

Additional index words. dissolved organic C, dissolved organic matter, compost, macronutrients, St. Augustinegrass

\begin{abstract}
Compost application to turfgrasses may contribute to accumulation of macronutrients in soil and eventually pose leaching and runoff hazards. The objectives of this study were to determine the influence of compost on soil-dissolved organic C (DOC) and accumulation of $\mathrm{NH}_{4} \mathrm{OAc}$-EDTA-extractable and water-soluble nitrogen $(\mathrm{N})$, phosphorus (P), potassium (K), calcium (Ca), magnesium (Mg), and sulfur (S) in St. Augustinegrass [Stenotaphrum secundatum (Walt.) Kuntze] turf. Dissolved organic C increased from 3 to 29 months after application for unamended and compost-amended soils, indicating contribution from decomposition of both compost and St. Augustinegrass residues. Dissolved organic $\mathrm{C}$ was $75 \%, 78 \%$, and $101 \%$ greater 29 months after application of 0,80 , and $160 \mathrm{mg} \cdot \mathrm{ha}^{-1}$ of compost, respectively, than before application. Dissolved organic $C$ and macronutrients exhibited considerable seasonal variation, because DOC and EDTA-extractable $\mathrm{P}, \mathrm{Ca}, \mathrm{Mg}$, and $\mathrm{S}$ increased after compost application, whereas $\mathrm{NO}_{3}$ declined. Water-soluble $\mathrm{K}$, Ca, and $\mathrm{Mg}$ declined, whereas $\mathrm{P}$ and $S$ increased from 0 to 29 months. Similar seasonal changes in macronutrient concentrations occurred for unamended and compost-amended soil, indicating that composts, in addition to turfgrass residues, influenced DOC and macronutrient dynamics. Long-term nutrient accumulation occurred in compost-amended turfgrass, but seasonal dynamics were more related to the growth stage of turfgrass than compost. Formation of DOC-cation complexes appeared to contribute to macronutrient mobility, because decreases in DOC and nutrient concentrations occurred during turfgrass dormancy in winter and after high precipitation levels, indicating the potential for leaching of DOC-associated nutrients from soil.
\end{abstract}

Considerable research has been conducted on the fate of nutrients in compostamended agricultural soils, but minimal information is available on the use of turfgrass for compost application and subsequent effects on soil organic matter and nutrient dynamics. Problems commonly associated with land compost application include nutrient accumulation in soil, leaching, and runoff. The long-term cycling of nutrients in compost-amended soils is dependent on compost quantity and quality in addition to environmental factors such as soil properties, vegetation patterns, and precipitation (McDowell, 2003). Ultimately, organic matter and soil-dissolved organic $\mathrm{C}$ (DOC) influence nutrient dynamics in soil through adsorption and complexation of nutrients, which impacts their bioavailability (Chantigny, 2003).

Received for publication 18 Aug. 2006. Accepted for publication 23 Sept. 2006.

${ }^{1}$ To whom reprint requests should be addressed; e-mail alwr@ifaas.ufl.edu.
Compost application to soils often induces increases in soil organic matter and DOC for years (Chantigny et al., 2002; Chantigny, 2003), however, if wastes are rapidly decomposed in soil, DOC quickly returns to background levels (Franchini et al., 2001). Seasonal dynamics of DOC are related to the growth stages of plants and decomposition of soil organic matter and compost (Chantigny, 2003) and the decomposition byproducts of root exudates and microbial metabolites (Marschner and Kalbitz, 2003). Dissolved organic matter is often considered refractory but mobile in soils (Qualls and Haines, 1992). Accumulation of nutrients in compost-amended soils may pose environmental hazards, because compost decomposition increases dissolved organic matter, which complexes nutrients (Ashworth and Alloway, 2004; Kaschl et al., 2002). Dissolved organic matter may also coat soil particle surfaces, reducing their ability to bind nutrient cations and enhancing their mobility in soils (McCracken et al., 2002; Qualls and Haines, 1992).
Although total soil nutrient levels increase after compost addition, the production and accumulation of available nutrients depends on the decomposition of compost and native soil organic matter. Thus, measurement of nutrient availability indicates the extent of compost decomposition and nutrient adsorption to soil. Different soil extraction methods may be related to the degree of nutrient availability (Van Raij, 1994). The use of acidified $\mathrm{NH}_{4} \mathrm{OAc}$-EDTA for extraction of plant-available macronutrients is used for a wide variety of soils (Hons et al., 1990), whereas water-soluble nutrients represent the most readily bioavailable chemical form (Linehan et al., 1985; Seguin et al., 2004). The $\mathrm{NH}_{4} \mathrm{OAc}-$ EDTA extracts exchangeable or adsorbed cations from soil colloids, organic matter, and other labile pools, whereas water extracts nutrients free in solution and those weakly associated with dissolved organic matter.

Turfgrasses are intensively managed and capable of sequestering large amounts of nutrients (Vietor et al., 2002), but research pertaining to compost effects on DOC and macronutrient dynamics is needed. The fate of compost and impacts on nutrient accumulation in turfgrass soils could be assessed by measuring seasonal changes in soil properties and macronutrient concentrations after compost application. A study was initiated to determine impacts of compost source and application rate on the accumulation and availability of DOC and EDTA-extractable and water-soluble macronutrients in St. Augustinegrass turf.

\section{Materials and Methods}

Site description. A field study was established at the Texas A\&M University Turfgrass Field Laboratory at College Station, TX, in July 2001 on a Boonville fine sandy loam (fine, smectitic, thermic Chromic Vertic Albaqualfs) with $\mathrm{pH}$ 7.3. Average annual rainfall is $980 \mathrm{~mm}$ and temperature is $20{ }^{\circ} \mathrm{C}$. The site was previously under pasture before St. Augustinegrass [Stenotaphrum secundatum (Walt.) Kuntze] establishment.

A completely randomized experiment with three compost sources and an unamended control and two application rates was established on field plots $\left(20 \mathrm{~m}^{2}\right.$ each $)$ replicated four times. The compost sources were DilloDirt (City of Austin, TX), Bryan compost (City of Bryan, TX), and Nature's Way compost (Nature's Way Resources, Conroe, TX) applied at 80 and $160 \mathrm{mg} \cdot \mathrm{ha}^{-1}$, which were equivalent to a $2.5-$ and $5.0-\mathrm{cm}$ depths. DilloDirt and Bryan Compost are cocomposted landscape wastes and municipal biosolids, whereas Nature's Way consists of composted landscape wastes with small amounts of manure. Characterization data for the Boonville soil and compost sources are presented in Table 1. Soil was chiseled to a depth of $35 \mathrm{~cm}$ and tilled to $15 \mathrm{~cm} 2$ months before compost application. Composts were applied by rototilling into the top $15 \mathrm{~cm}$ of soil in July 2001. Unamended 
Table 1. Soil $\mathrm{pH}$, soil organic $\mathrm{C}$, and $\mathrm{NH}_{4} \mathrm{OAc}$-extractable nutrient concentrations for compost sources and turfgrass soils before compost addition.

\begin{tabular}{llcccc}
\hline Parameter & Units & $\begin{array}{c}\text { Soil under } \\
\text { St. Augustinegrass }\end{array}$ & Bryan compost & DilloDirt & Nature's Way \\
\hline pH & - & 7.5 & - & - & -163 \\
Organic C & $\mathrm{g} \cdot \mathrm{kg}^{-1}$ & 12 & 246 & - & - \\
Nitrate-N & $\mathrm{mg} \cdot \mathrm{kg}^{-1}$ & 22 & - & 12,755 & 1365 \\
Phosphorus & $\mathrm{mg} \cdot \mathrm{kg}^{-1}$ & 168 & 4091 & 7672 & 2588 \\
Potassium & $\mathrm{mg} \cdot \mathrm{kg}^{-1}$ & 145 & 3949 & 108 & 18 \\
Calcium & $\mathrm{g} \cdot \mathrm{kg}^{-1}$ & 4.5 & 1281 & 5328 & 1599 \\
Magnesium & $\mathrm{mg} \cdot \mathrm{kg}^{-1}$ & 145 & 3325 & 7838 & 1360 \\
Sulfur & $\mathrm{mg} \cdot \mathrm{kg}^{-1}$ & 31 & & & \\
\hline
\end{tabular}

and compost-amended soil was then plugged with St. Augustinegrass. Turfgrass received supplemental $\mathrm{NH}_{4} \mathrm{NO}_{3}$ at $72 \mathrm{~kg}$ of nitrogen (N) per ha $\mathrm{ha}^{-1}$ in 2001 and $49 \mathrm{~kg} \cdot \mathrm{N} \cdot \mathrm{ha}^{-1}$ in 2002, but no $\mathrm{N}$ was applied in 2003. Turfgrass was mowed to maintain a $3.5-\mathrm{cm}$ canopy height and clippings were returned to plots. To minimize moisture stress, supplemental irrigation was provided at $12 \mathrm{~mm} / \mathrm{d}^{-1}$ for $60 \mathrm{~d}$ after plugging followed by $12 \mathrm{~mm}$ every $3 \mathrm{~d}$ until Oct. 2001. Thereafter, $6 \mathrm{~mm}$ of water was applied at 3-d intervals during the growing season or at onset of drought stress symptoms.

Soil sampling and analysis. Five soil cores $(2.5-\mathrm{cm}$ diameter) were taken from each plot to a depth of $15 \mathrm{~cm}$ and composited. Samples were taken in July 2001 before compost application and in Oct. 2001, Mar. 2002, June 2002, Nov. 2002, June 2003, and Dec. 2003, corresponding to 3, 8, 11, 16, 23, and 29 months after application of compost and St. Augustinegrass establishment.

Soil was dried at $65{ }^{\circ} \mathrm{C}$ and passed through a 2-mm sieve. Subsamples were extracted with water (1:2 soil:water) by stirring for $30 \mathrm{~min}$ followed by measurement of $\mathrm{pH}$ (Schofield and Taylor, 1955) and electrical conductivity (EC) (Rhoades, 1982). Nitrate was extracted with $2.0 \mathrm{M}$ $\mathrm{KCl}$ and analyzed by cadmium reduction (Dorich and Nelson, 1984). Soil organic C was measured by automated dry combustion using an Elementar VarioMax CN analyzer (Elementar Americas, Mt. Laurel, NJ). For DOC measurement, $7 \mathrm{~g}$ of soil was shaken with $28 \mathrm{~mL}$ of distilled water for $1 \mathrm{~h}$ followed by centrifugation and filtration through 0.45 $\mu \mathrm{m}$ filters (Wright et al., 2005). Extracts were analyzed for DOC by persulfate oxidation using a Model 700 Total Organic Carbon Analyzer (O.I. Analytical, College Station, TX) and for water-extractable phosphorus $(\mathrm{P})$, potassium $(\mathrm{K})$, calcium $(\mathrm{Ca})$, magnesium $(\mathrm{Mg})$, and sulfur (S) by ICP-AES (Spectro Analytical Instruments, Marlborough, MA). Exchangeable or plant-available P, K, Ca, $\mathrm{Mg}$, and $\mathrm{S}$ was extracted with acidified $\mathrm{NH}_{4} \mathrm{OAc}-\mathrm{EDTA}$ (Hons et al., 1990) and analyzed by ICP-AES (Franson, 1989). Total monthly precipitation during the 29 months after compost application is presented in Figure 1 as well as the active growth and dormant periods of St. Augustinegrass. Soil sampling events encompassed both the growing season and dormant periods in addition to before and after rainfall events.
Nutrient concentrations and soil properties were analyzed using a completely randomized experimental design. Data were analyzed with CoStat (CoStat Statistical Software, 2003) and analysis of variance was used to determine significant differences among compost source, application rate, and sampling time. Few differences in soil properties were observed between compost sources, so data were averaged for presentation in figures. Separation of means was accomplished using the least significant difference, and Pearson's correlation coefficients were determined at $P<0.05$.

\section{Results and Discussion}

Soil $\mathrm{pH}$ and electrical conductivity. Soil $\mathrm{pH}$ did not vary between compost application rates but was significantly higher for unamended (7.9) than composted-amended soil (7.7) from 8 to 29 months (Fig. 2). In fact, composts tended to buffer the soil to changes in $\mathrm{pH}$. Turfgrass was irrigated to aid in establishment and during periods of drought, and salts in irrigation water may have been responsible for soil $\mathrm{pH}$ increases after compost application. Moreover, addition of composts can cause adsorption of dissolved organic matter to soil particle surfaces or coat soil particles (Kalbitz et al., 2000), reducing the number of exchange sites capable of reacting with cations from irrigation water, which may explain the lower $\mathrm{pH}$ for compost-amended than unamended soil.

Soil EC was unaffected by application rate and was in fact significantly higher for unamended than compost-amended soil (Fig. 2). Thus, composts did not contribute to soil $\mathrm{EC}$, and in fact tended to alleviate impacts of soluble salts. Soil EC exhibited considerable seasonal variation related to precipitation patterns, because soluble salts responsible for the increasing trend from 0 to 29 months leached from the soil surface after high precipitation at 16 months. Decreases in soil EC occurred during turfgrass dormant periods when irrigation was not provided.

Dissolved organic $C$. For unamended and compost-amended soils, DOC significantly increased up to 11 months after application, but declined at 16 months and then increased to 29 months (Fig. 2). Because no compost was added to unamended soil, the increases in DOC were attributed to $\mathrm{C}$ contribution from St. Augustinegrass roots and residues or from decomposition of residues generated during

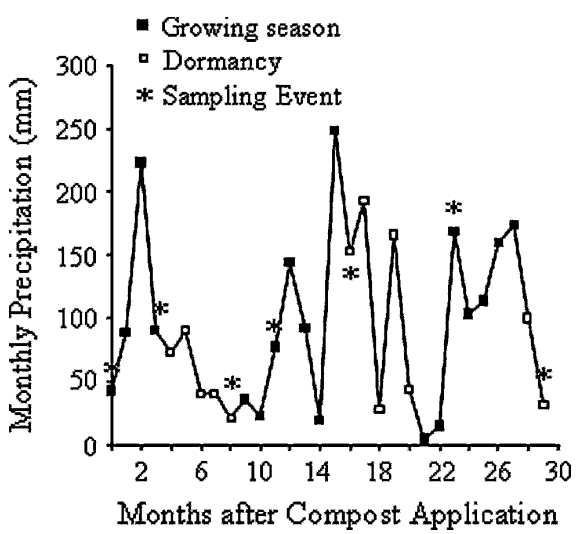

Fig. 1. Monthly precipitation for the 29 months after compost application in July 2001. The growing season and dormant periods for St. Augustinegrass are noted. Soil sampling occurred at $0,3,8,11,16,23$, and 29 months after compost application.
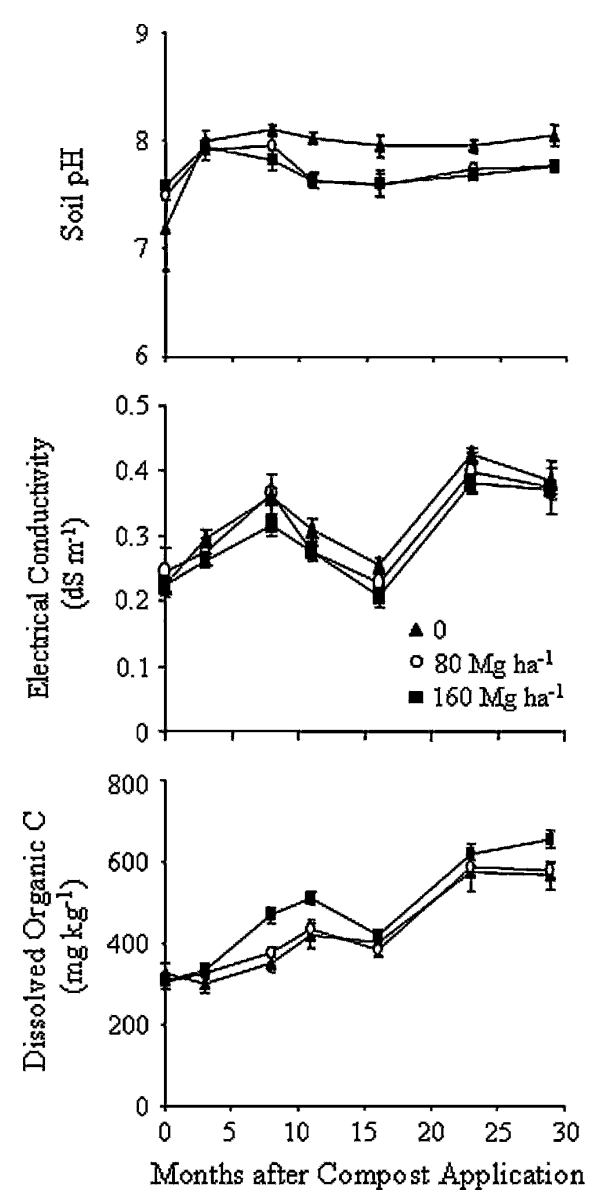

Fig. 2. Soil pH, electrical conductivity (EC), and dissolved organic C (DOC) under St. Augustinegrass after application of compost at 0,80 , and $160 \mathrm{mg} \cdot \mathrm{ha}^{-1}$. Bars represent the SE of the mean.

prior land use. Composts applied at 160 $\mathrm{mg} \cdot \mathrm{ha}^{-1}$ had $11 \%$ significantly higher DOC than at $80 \mathrm{mg} \cdot \mathrm{ha}^{-1}$ and $12 \%$ higher DOC than unamended soil.

Dissolved organic C exhibited cyclical seasonal patterns after compost application 
as evidenced by lower concentrations during the winter sampling at 16 months. Dissolved organic C was significantly lower for all compost treatments and unamended soil at 16 than at 11 and 23 months, suggesting that the decline was not related to compost but rather reduced St. Augustinegrass growth during winter dormancy, lower microbial activity resulting from lower temperature during winter, and decreased organic matter decomposition rates. Turfgrass growth is more vigorous from late spring to summer with a dormant period from late autumn to winter (Trenholm et al., 2000). Turfgrasses often produce high levels of belowground biomass (Trenholm et al., 2000), which increase soil organic $\mathrm{C}$ and DOC levels. Because St. Augustinegrass production levels are lower in cooler than warmer months, a lower contribution of turfgrass residues likely led to lower DOC at 16 months. Dissolved organic matter from compost added to sandy soils leached from the root zone within 1 year (Kaschl et al., 2002). Thus, seasonal changes in DOC in our study may have resulted not only from decomposition of compost, but also from decomposition of native soil organic matter and St. Augustinegrass residues.

Nitrate. Extractable $\mathrm{NO}_{3}$ exhibited no treatment effects and averaged $22 \mathrm{mg} \cdot \mathrm{N} \cdot \mathrm{kg}^{-1}$ before compost application, but levels significantly declined by 3 months to an average of $6 \mathrm{mg} \cdot \mathrm{N} \cdot \mathrm{kg}^{-1}$, and concentrations remained at this level throughout the study (data not shown). Soil $\mathrm{NO}_{3}$ levels are often low in turfgrass soils as a result of plant uptake and immobilization (Hadas et al., 1996) and by leaching from the soil surface (Johnson et al., 1995). Because the growth of turfgrass generally requires considerable quantities of $\mathrm{N}$ (Trenholm et al., 2000), $\mathrm{N}$ mineralized from composts was likely rapidly assimilated by St. Augustinegrass resulting in low $\mathrm{NO}_{3}$ levels for both compost-amended and unamended soil.

Phosphorus. EDTA-extractable P increased by 11 months for compost-amended soil, but did not increase from 11 to 29 months (Fig. 3). Phosphorus concentrations did not change from 0 to 29 months for unamended soil and averaged $200 \mathrm{mg} \cdot \mathrm{kg}^{-1}$. EDTA-extractable P at $160 \mathrm{mg} \cdot \mathrm{ha}^{-1}$ was $33 \%$ and $82 \%$ higher than at $80 \mathrm{mg} \cdot \mathrm{ha}^{-1}$ and for unamended soil. Similar to DOC and other macronutrients, $\mathrm{P}$ exhibited seasonal fluctuations and significantly declined during winter dormancy at 16 months. The decline at 16 months was more pronounced at the highest application rate, but also occurred for unamended soil; thus, composts were not the main factor influencing seasonal fluctuations. Likely, the growth stages of turfgrass, in addition to precipitation, controlled seasonal $\mathrm{P}$ variability.

Similar to EDTA-extractable P, unamended soil had significantly lower waterextractable $\mathrm{P}$ than compost-amended soil. However, seasonal variation in water-extractable $P$ differed from EDTA-extractable P. Although maximum EDTA-extractable levels were obtained at 11 months, waterextractable $\mathrm{P}$ reached maximum levels at

Phosphorus
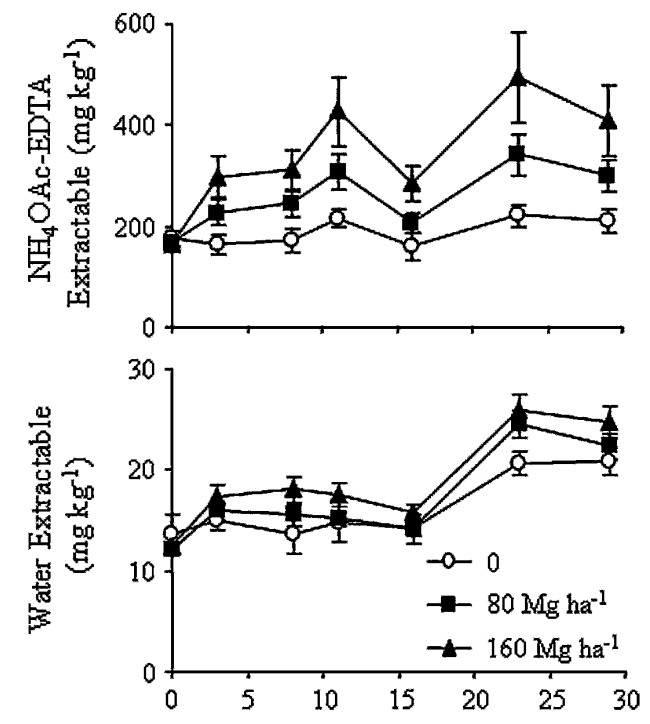

Months after Compost Application

Fig. 3. Seasonal dynamics of $\mathrm{NH}_{4} \mathrm{OAc}-\mathrm{EDTA}$ and water-extractable $\mathrm{P}$ and $\mathrm{K}$ for St. Augustinegrass after compost application at 0,80 , and $160 \mathrm{mg} \cdot \mathrm{ha}^{-1}$. Bars represent the SE of the mean.

23 months. Furthermore, although EDTAextractable $\mathrm{P}$ did not change from 0 to 29 months for unamended soil, water-extractable $\mathrm{P}$ increased during this timeframe. Composts had a greater effect on EDTAextractable than water-extractable P. EDTAextractable $\mathrm{P}$ was significantly higher than water-extractable P throughout 29 months, and effects of application rate were greater for EDTA-extractable P. Thus, increases in $\mathrm{P}$ concentrations after compost application may enhance the potential for $\mathrm{P}$ runoff. Dissolved organic C was significantly correlated with EDTA-extractable $\mathrm{P}(\mathrm{r}=0.70)$ and water-extractable $\mathrm{P}(\mathrm{r}=0.92)$. EDTAextractable $\mathrm{P}$ was also significantly related to EDTA-extractable $\mathrm{Ca}(\mathrm{r}=0.81)$ and $\mathrm{Mg}$ $(\mathrm{r}=0.94)$.

Potassium. Both EDTA- and waterextractable $\mathrm{K}$ were influenced by compost application rate (Fig. 3). Compost application increased EDTA-extractable $\mathrm{K}$ by 3 months, and levels did not change until 11 months, when $\mathrm{K}$ declined to background levels. Meanwhile, water-extractable $\mathrm{K}$ levels decreased after compost application and for unamended soil, suggesting turfgrass-mediated seasonal changes. EDTA-extractable $\mathrm{K}$ at $160 \mathrm{mg} \cdot \mathrm{ha}^{-1}$ was $23 \%$ and $53 \%$ higher than $80 \mathrm{mg} \cdot \mathrm{ha}^{-1}$ and unamended soil, and for water-extractable $\mathrm{K}$, it was $21 \%$ and $36 \%$ higher than $80 \mathrm{mg} \cdot \mathrm{ha}^{-1}$ and unamended soil. Both EDTA-extractable and water-extractable $\mathrm{K}$ exhibited significant declines at 16 months relative to proximal sampling times for both compost-amended and unamended soil, which, similar to DOC, indicated potential leaching losses of $\mathrm{K}$ occurred after high precipitation levels. In contrast to P, EDTAand water-extractable $\mathrm{K}$ were not correlated with DOC.

Calcium. Similar to EDTA-extractable P, EDTA-extractable $\mathrm{Ca}$ generally increased from 0 to 29 months after compost application with a significant decline at 16 months (Fig. 4). EDTA-extractable Ca was $46 \%$ and $15 \%$ higher at 29 months than before application for 160 and $80 \mathrm{mg} \cdot \mathrm{ha}^{-1}$, respectively, whereas $\mathrm{Ca}$ for unamended soil did not increase by 29 months. In contrast to EDTA-extractable $\mathrm{Ca}$, water-extractable $\mathrm{Ca}$ significantly decreased by 3 months, then increased to 29 months, and was $57 \%$ and $38 \%$ higher at 29 than 3 months for 160 and $80 \mathrm{mg} \cdot \mathrm{ha}^{-1}$. EDTA-extractable Ca concentrations were significantly highest at 160 $\mathrm{mg} \cdot \mathrm{ha}^{-1}$, being $16 \%$ higher than $80 \mathrm{mg} \cdot \mathrm{ha}^{-1}$ and $28 \%$ higher than unamended soil. For water-extractable $\mathrm{Ca}$, however, no differences between application rates were observed. Whereas EDTA-extractable $\mathrm{Ca}$ was significantly correlated with DOC $(r=0.56)$, waterextractable $\mathrm{Ca}$ was not.

Magnesium. Trends in $\mathrm{Mg}$ were similar to $\mathrm{Ca}$ for both EDTA and water extractions. Increasing the compost application rate increased EDTA- but not water-extractable $\mathrm{Mg}$ (Fig. 4). EDTA-extractable $\mathrm{Mg}$ at 160 $\mathrm{mg} \cdot \mathrm{ha}^{-1}$ was $19 \%$ and $49 \%$ greater than 80 $\mathrm{mg} \cdot \mathrm{ha}^{-1}$ and unamended soil and increased from 0 to 29 months with the characteristic significant decline at 16 and 29 months during winter dormancy. EDTA-extractable $\mathrm{Mg}$ at 29 months was $48 \%$ and $15 \%$ greater than before application for 160 and $80 \mathrm{mg} \cdot \mathrm{ha}^{-1}$, respectively. In contrast to EDTA-extractable $\mathrm{Mg}$, water-extractable $\mathrm{Mg}$ decreased rapidly after compost application and for unamended soil by 3 months, and levels averaged $15 \mathrm{mg} \cdot \mathrm{kg}^{-1}$ from 3 to 29 months. Irrigation during turfgrass establishment may have leached water-soluble nutrients from soil, which explains decreases in water-extractable $\mathrm{Ca}$ and $\mathrm{Mg}$ by 3 months after compost application. EDTA-extractable $\mathrm{Mg}$ was significantly related to DOC 


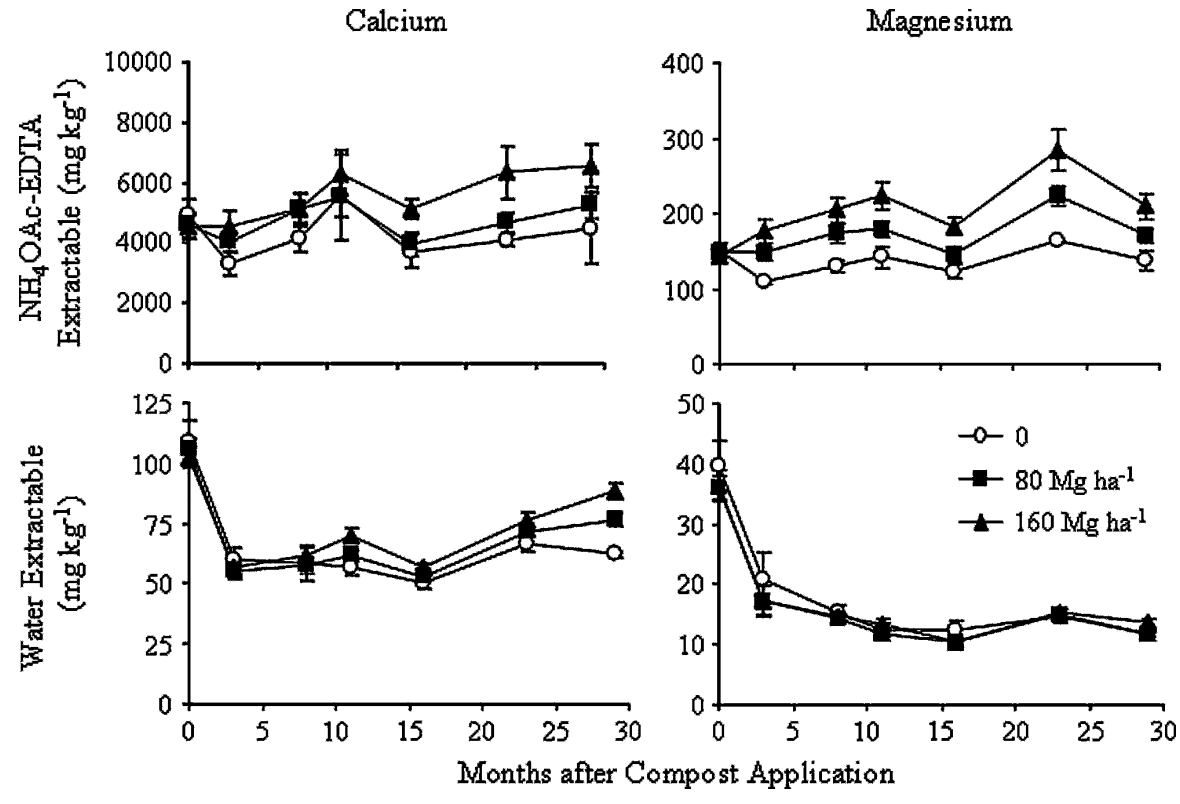

Fig. 4. Seasonal dynamics of $\mathrm{NH}_{4} \mathrm{OAc}-\mathrm{EDTA}$ and water-extractable $\mathrm{Ca}$ and $\mathrm{Mg}$ for St. Augustinegrass after compost application at 0,80 , and $160 \mathrm{mg} \cdot \mathrm{ha}^{-1}$. Bars represent the sE of the mean.

$(\mathrm{r}=0.65)$, but no relationships existed between water-extractable $\mathrm{Mg}$ and DOC.

Sulfur. Both EDTA-extractable and water-extractable $\mathrm{S}$ were highest at 160 $\mathrm{mg} \cdot \mathrm{ha}^{-1}$, being $21 \%$ and $33 \%$ greater than $80 \mathrm{mg} \cdot \mathrm{ha}^{-1}$ and unamended soil (Fig. 5). In contrast to water-extractable $\mathrm{K}, \mathrm{Ca}$, and $\mathrm{Mg}$, but similar to water-extractable $\mathrm{P}$, waterextractable $\mathrm{S}$ increased from 0 to 29 months for compost-amended and unamended soil. EDTA-extractable S was $98 \%, 69 \%$, and $34 \%$ greater at 29 months than before compost application for $160 \mathrm{mg} \cdot \mathrm{ha}^{-1}, 80 \mathrm{mg} \cdot \mathrm{ha}^{-1}$, and unamended soil, respectively. Soil EC was significantly correlated with EDTA $(r=$ $0.44)$ and water-extractable $S(r=0.91)$.
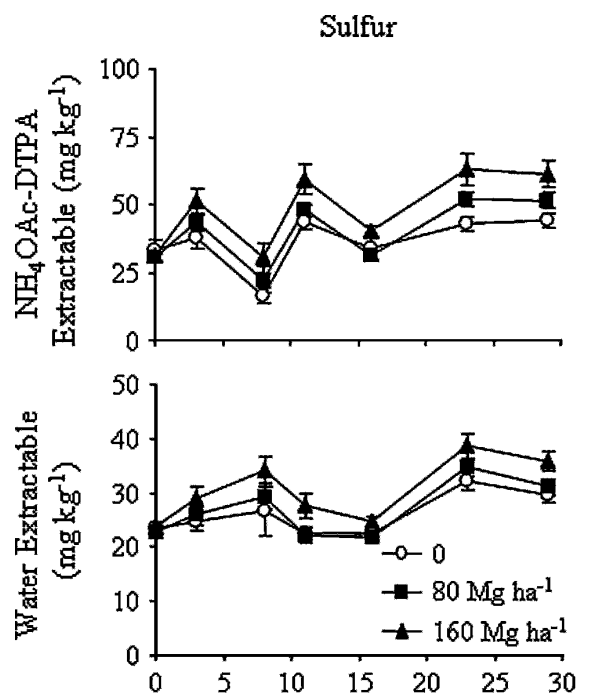

Months after Compost Application

Fig. 5. Seasonal dynamics of $\mathrm{NH}_{4} \mathrm{OAc}-\mathrm{EDTA}$ and water-extractable $\mathrm{S}$ for St. Augustinegrass after compost application at 0,80 , and $160 \mathrm{mg} \cdot \mathrm{ha}^{-1}$. Bars represent the SE of the mean.
Soil-dissolved organic $C$ and turfgrass impacts on macronutrients. Potential hazards associated with compost application to soils include the accumulation of nutrients and resulting leaching losses. Although considerable seasonal variation in macronutrient concentrations existed, EDTA-extractable P, $\mathrm{Ca}, \mathrm{Mg}$, and $\mathrm{S}$ showed increasing trends after compost application, whereas $\mathrm{NO}_{3}$ and EDTA-extractable $\mathrm{K}$ decreased after application. For water-extractable nutrients, $\mathrm{P}$ and $\mathrm{S}$ increased, but all others showed significant declining trends that did not follow DOC trends. Phosphorus accumulation in soils often occurs after organic amendment addition and may ultimately pose a leaching hazard (Korboulesky et al., 2002). However, similar trends in nutrient concentrations after compost application occurred for both compost-amended and unamended soils, suggesting that composts were not entirely responsible, but rather served to increase the magnitude of the macronutrient response to seasonal changes.

Both turfgrass and compost decomposition were responsible for DOC increases from 0 to 29 months, because similar trends occurred for unamended and compostamended soil. Dissolved organic matter often complexes nutrient cations, which increases their solubility and potential movement through soils (Stevenson and Cole, 1999). Elevated macronutrient concentrations were observed after prolonged dry periods, whereas concentrations were generally lowest after periods of high precipitation levels, indicating that complexation of nutrient cations by dissolved organic matter and subsequent vertical movement in soil after precipitation events explained seasonal nutrient fluctuations in St. Augustinegrass turf. Dissolved organic C and EDTA-extractable $\mathrm{P}, \mathrm{Ca}, \mathrm{Mg}$, and $\mathrm{S}$ exhibited similar seasonal trends, including a general increase over time and a significant decrease at 16 months, suggesting leaching losses of DOC-associated nutrients were incited by high precipitation levels during winter. High precipitation levels preceding other sampling times did not result in losses of these nutrients, because these events occurred during the growing season when nutrients were assimilated by St. Augustinegrass. Thus, potential leaching losses of DOC-associated macronutrients may occur most readily during turfgrass dormancy and at high precipitation levels.

Nutrient cations are seldom present in soil solution at high concentrations as a result of adsorption to soil particle surfaces and organic matter (Stevenson and Cole, 1999). Therefore, soluble nutrients are more apt to 2leach than EDTA-extractable nutrients, which are generally associated with soil colloids and particle surfaces (Cancela et al., 2002; Stevenson and Cole, 1999). Hence, EDTA extracts had significantly higher nutrient concentrations than water extracts (Figs. 3-5). Compost incorporation into soil likely increases compost decomposition compared with surface application; thus, concentrations and availability of nutrients may be higher after compost incorporation. Thus, application method may also affect the fate of nutrients in compostamended soil.

Soil $\mathrm{pH}$ appeared to have more influence on water-extractable than EDTA-extractable macronutrients, because $\mathrm{pH}$ was significantly negatively related to water-extractable $\mathrm{K}(\mathrm{r}=$ $-0.44), \mathrm{Ca}(\mathrm{r}=-0.69)$, and $\mathrm{Mg}(\mathrm{r}=-0.56)$, but not to EDTA-extractable macronutrients. Sorption of DOC and formation of DOCcation complexes may be $\mathrm{pH}$-dependent (Temminghoff et al., 1997). As soil $\mathrm{pH}$ increases above neutrality, DOC sorption to soil becomes weaker and potential for formation of DOC-cation complexes increases (Romkens et al., 1996). For the high $\mathrm{pH}$ soil of this study, compost likely promoted the formation of DOC-cation complexes, subsequently increasing macronutrient mobility.

In summary, composts increased most EDTA-extractable macronutrient levels in soil. By 29 months after compost application, EDTA-extractable $\mathrm{P}, \mathrm{Ca}, \mathrm{Mg}$, and $\mathrm{S}$ accumulated in surface soil, whereas $\mathrm{NO}_{3}$ rapidly decreased to below background levels. Potassium levels initially increased but decreased to background levels by 16 months. Waterextractable $\mathrm{P}$ and $\mathrm{S}$ also increased after compost application. Significantly higher levels of EDTA- than water-extractable nutrients indicate considerable quantities of nutrients are absorbed to soil particles or complexed by organic matter and thus may pose leaching and runoff hazards. Similar trends in macronutrient concentrations were observed for both compost-amended and unamended soils, indicating that seasonal variation was more directly related to the growth stages of St. Augustinegrass, and subsequent effects on DOC, than compost application. In fact, compost application only increased macronutrient concentrations but 
did not appear to influence seasonal trends. Complexation of macronutrient cations with DOC, and subsequent leaching below the surface soil, may explain seasonal macronutrient dynamics after compost application.

\section{Literature Cited}

Ashworth, D.J. and B.J. Alloway. 2004. Soil mobility of sewage sludge-derived dissolved organic matter, copper, nickel, and zinc. Environ. Pollut. 127:137-144.

Cancela, R.C., C.A. Abreu, and A.P. Gonzalez. 2002. DTPA and Mehlich-3 micronutrient extractability in natural soils. Commun. Soil Sci. Plant Anal. 33:2879-2893.

Chantigny, M.H. 2003. Dissolved and waterextractable organic matter in soils: A review on the influence of use and management practices. Geoderma 113:357-380.

Chantigny, M.H., D.A. Angers, and P. Rochette. 2002. Fate of carbon and nitrogen from animal manure and crop residues in wet and cold soils. Soil Biol. Biochem. 34:509-517.

CoStat Statistical Software. 2003. CoHort v. 6.2, Monterey, CA.

Dorich, R.A. and D.W. Nelson. 1984. Evaluation of manual cadmium reduction methods for determination of nitrate in potassium chloride extracts of soils. Soil Sci. Soc. Amer. J. 48:7275.

Franchini, J.C., F.J. Gonzalez-Vila, F. Cabrera, M. Miyazawa, and M.A. Pavan. 2001. Rapid transformations of plant water-soluble organic compounds in relation to cation mobilization in an acid oxisol. Plant Soil 231:55-63.

Franson, M.A.H. 1989. 3120. Metals by plasma emission spectroscopy. Standard methods for examination of water and wastewater. Amer. Publ. Health Assn., Washington, DC

Hadas, A., L. Kautsky, and R. Portney. 1996. Mineralization of composted manure and microbial dynamics in soil as affected by long-term nitrogen management. Soil Biol. Biochem. 28:733-738.

Hons, F.M., L.A. Larson-Vollmer, and M.A. Locke. 1990. $\mathrm{NH}_{4} \mathrm{OAc}$-EDTA extractable phosphorus as a soil test procedure. Soil Sci. 149: 249-256.

Johnson, A.F., D.M. Vietor, F.M. Rouquette, V.A Haby, and M.L. Wolfe. 1995. Estimating probabilities of nitrogen and phosphorus loss from animal waste application, p. 411-418. In: K. Steel (ed.). Animal waste and the land-water interface. Lewis Publ., Boca Raton, FL.

Kalbitz, K., S. Solinger, J.H. Park, B. Michalzik, and E. Matzer. 2000. Controls on the dynamics of dissolved organic matter in soils: A review. Soil Sci. 165:277-304.

Kaschl, A., V. Romheld, and Y. Chen. 2002. The influence of soluble organic matter from municipal solid waste compost on trace metal leaching in calcareous soils. Sci. Total Environ. 291:45-57.

Korboulesky, N., S. Dupouyet, and G. Bonin. 2002. Environmental risks of applying sewage sludge compost to vineyards: Carbon, heavy metals, nitrogen, and phosphorus accumulation. J. Environ. Qual. 31:1522-1527.

Linehan, D.J., A.H. Sinclair, and M.C. Mitchell. 1985. Mobilization of $\mathrm{Cu}, \mathrm{Mn}$, and $\mathrm{Zn}$ in the soil solution of barley rhizospheres. Plant Soil 86:147-149.

Marschner, B. and K. Kalbitz. 2003. Controls of bioavailability and biodegradability of dissolved organic matter in soils. Geoderma 113:211-235.

McCracken, K.L., W.H. McDowell, R.D. Harter, and C.V. Evans. 2002. Dissolved organic carbon retention in soils. Soil Sci. Soc. Amer. J. 66:563-568.

McDowell, W.H. 2003. Dissolved organic matter in soils-Future directions and unanswered questions. Geoderma 113:179-186.
Qualls, R.G. and B.L. Haines. 1992. Biodegradability of dissolved organic matter in forest throughfall, soil solution, and stream water. Soil Sci. Soc. Amer. J. 56:578-586.

Rhoades, J.D. 1982. Soluble salts, p. 167-178. In: A.L. Page, R.H. Miller, and D.R. Keeney (eds.). Methods of soil analysis, part 2. 2nd ed. ASA and SSSA, Madison, WI.

Romkens, P.F., J. Bril, and W. Salomons. 1996. Interaction between $\mathrm{Ca}$ and dissolved organic carbon: Implications for metal mobilization. Appl. Geochem. 11:109-115.

Schofield, R.K. and A.W. Taylor. 1955. The measurement of soil pH. Soil Sci. Soc. Amer. Proc. 19:164-167.

Seguin, V., C. Gagnon, and F. Courchesne. 2004. Changes in water-extractable metals, $\mathrm{pH}$, and organic carbon concentrations at the soil-root interface of forested soils. Plant Soil 260:1-17.

Stevenson, F.J. and M.A. Cole. 1999. Micronutrients and toxic metals, p. 369-418. In: F.J. Stevenson and M.A. Cole (eds.). Cycles of soils. John Wiley \& Sons, NY.

Temminghoff, E.J.M., S.E.A. van der Zee, and F.A.M. de Haan. 1997. Copper mobility in a copper contaminated sandy soil as affected by $\mathrm{pH}$, and solid and dissolved organic matter. Environ. Sci. Technol. 31:1109-1115.

Trenholm, L.E., J.L. Cisar, and J.B. Unruh. 2000 St. Augustinegrass for Florida lawns. Florida Cooperative Extension Publ. ENH5. Univ. of FL.

Van Raij, B. 1994. New diagnostic techniques and universal soil extractants. Commun. Soil Sci. Plant Anal. 25:799-816.

Vietor, D.M., E.N. Griffith, R.H. White, T.L. Provin, J.P. Muir, and J.C. Read. 2002. Export of manure phosphorus and nitrogen in turfgrass sod. J. Environ. Qual. 31:1731-1738.

Wright, A.L., T.L. Provin, F.M. Hons, D.A Zuberer, and R.H. White. 2005. Dissolved organic $\mathrm{C}$ in compost-amended bermudagrass turf. HortScience 40:830-835. 